Saint Louis University School of Law

Scholarship Commons

All Faculty Scholarship

2011

Missouri Provides Cost of Sentences and Recidivism Data: What

Does Cost Have to Do with Justice?

Michael A. Wolff

Follow this and additional works at: https://scholarship.law.slu.edu/faculty

Part of the Criminal Law Commons, and the Criminal Procedure Commons 
S A I N T L O U I S

$\begin{array}{llllllllll}U & N & \text { I } & V & E & R & S & \text { I } & T & Y\end{array}$

\section{SCHOOL OF LAW}

\section{SAINT LOUIS UNIVERSITY SCHOOL OF LAW Legal Studies Research Paper Series}

No. $2011-30$

Missouri Provides Cost of Sentences and Recidivism Data: What Does Cost have to do With Justice?

Michael A. Wolff

Forthcoming in the Federal Sentencing Reporter

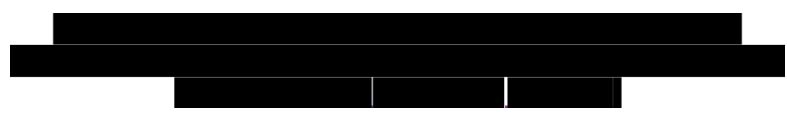




\title{
Missouri Provides Cost of Sentences and Recidivism Data: What Does Cost have to do With Justice?
}

\author{
Michael A. Wolff ${ }^{1}$
}

When the media reported in 2010 that Missouri Sentencing Advisory Commission is listing the "cost" of each sentencing option on its Web site, the reaction ranged from "outrageous" to "good idea."2 Now that more than a year has passed and the world has not ended, the time for cool reflection is here; my purpose is to set forth the context and rationale for this innovation.

Missouri has a discretionary sentencing regimen. Judges are allowed to sentence within the authorized ranges of four felony classes. Although some offenses are subject to mandatory minimum prison time, the majority of offenses allow probation or a short prison sentence followed by probation (referred to as 120-day "shock" or treatment). Judges' discretion often is shaped by a plea agreement.

Layered onto this discretionary sentencing regimen is the work of the Missouri Sentencing Advisory Commission, an eleven-member group whose tiny budget (about $\$ 73,000$ per year) must suffice to create a system of recommended sentencing - a goal that the commission achieves through the cooperation of the Department of Corrections, the Board of Probation and Parole, and the judiciary.

The commission's System of Recommended Sentencing is based on the work of the corrections department's statisticians. ${ }^{3}$ The System of Recommended Sentences consists of a matrix of 300 recommended sentences that take into 
account the offense severity and the offender's prior criminal history. The recommended sentence for each offense is based on the felony class (there are four classes), the offense group (there are five offense groups) and a statistically computed measure of offense seriousness (there are three levels: low, medium and high).

The offender's prior criminal history is scored on a five-point range - level 1 is an offender with no prior felonies and no more than four misdemeanors; level 5 is an offender with four or more unrelated felonies and three or more unrelated prison sentences.

The offense severity part of the sentencing matrix uses an aggregation of offenses because if the recommended sentences were based on actual sentencing for each offense, there would be many offenses for which there are insufficient data to compute reliable sentencing averages - for instance, in 2010, there were sentences recommended for 385 different offenses, but only 82 offenses had more than 50 sentences in that year.

For each felony offense, the commission's sentencing recommendations list three suggested sentences -

(1) A "typical" sentence, which is statistically determined to be the most common for that offense for an offender with a particular criminal history.

(2) An "aggravated" sentence - that is, more than the typical - where the circumstances of the crime would indicate to the judge that a 
penalty more harsh than "typical" might be appropriate. If the offenders scores "poor" or "below average" on the risk assessment scale, the commission recommends that aggravated sentence.

A "mitigated" sentence - that is, less than typical - where the circumstances of the offense would warrant a lighter than typical sentence. The commission recommends a mitigating sentence where the offender is rated a "good" risk for not re-offending, unless there are aggravating circumstances shown by the facts of the crime. ${ }^{4}$

A judge can order a Sentencing Assessment Report, prepared by a probation officer, that discusses the details of the offense, the impact on the victim, if any, the criminal history of the offender, and an assessment of the risk of re-offending; the report sets forth the three ranges of punishment as determined by the sentencing commission - aggravated, typical, and mitigated sentencing options for that offense and that category of offender. Each of the three sentencing options also is accompanied by information, where a prison term is possible, as to the parole board's guidelines for release and the parole board's record of releases of similarly assessed offenders incarcerated for that offense or similar offense.

The sentencing commission, with the cooperation of the Department of Corrections and the Board of Probation and Parole, has developed this information-based system over the past seven years. The statisticians of the 
corrections department have maintained the data on which the system is based, data that have tracked Missouri offenders for at least the past 25 years. ${ }^{5}$

The commission and the department have made many modifications in the manner in which the data, the sentencing information, and risk assessment information are communicated to the judges, lawyers, probation officers, and to the public. ${ }^{6}$

\section{Automated Sentencing Information}

Because judges order Sentencing Assessment Reports only in about 20 percent of cases, the commission several years ago developed an Automated Sentencing Information feature on the commission's Web site, www.mosac.mo.gov. Based on surveys and anecdotal reports, the commission has found that attorneys use the Automated Sentencing Information feature to gather information for plea negotiation and, especially with defendants and their families, to get a realistic idea of the sentencing possibilities in the event of a guilty plea.

To use the Automated Sentencing Information feature, the user needs to put in 11 pieces of information, six of which include information related to the offender's prior criminal history, the offense charged, and the defendant's age, education level, job status (either at the time of offense or sentencing), and drug abuse status. ${ }^{7}$ These characteristics of the offender are statistically correlated with the risk of re-offending.

When the user enters this information, the Automated Recommended Sentencing Information feature will produce 
- the three options for a "recommended sentence,"

- an offender risk assessment,

- the expected time served for any prison sentence,

- the recidivism after two years for offender in this risk category who have been sentenced for this crime, and

- the costs of incarceration and supervision.

\section{An Example}

In an example, the commission presents a hypothetical offender who pleads guilty to second-degree robbery, which is the forcible taking of property (without causing injury or using a gun, which would be first-degree robbery); the offender is male, 20 years old, has a high school diploma, has no prior felonies, has had a part-time job for two months prior to his arrest, and he is suspected of substance abuse. $^{8}$ With these characteristics, the offender is rated "above average" on the risk assessment - a scale that ranks an offender "good" (lowest risk of recidivism), "above average," "average," or "poor" (highest risk of recidivism). The Automated Sentencing Information feature provides the following information as to each sentencing option:

- "Typical" sentence is a "Community Structured Sentence," a probation sentence with enhanced supervision. The cost for five years of supervision is $\$ 1,792$ per year, a total of $\$ 8,960$. "The rate of recidivism -- which means incarceration because of violation of supervision or committing a new offense within two years - for 
offenders with this offender's prior criminal history and risk rating is 29.7 percent." 9

- "Mitigating" sentence is regular probation. The cost per year is $\$ 1,354$, or $\$ 6,770$ for five years. "The recidivism rate is 29.7 percent for offenders with this individual's risk rating who are placed on probation for second-degree robbery."

- "Aggravating" sentence is five years in prison. For prison terms the Automated Sentencing Information feature lists the parole board's releasing data, which the commission describes as: "A person with this offender's prior criminal history and risk rating can be expected to serve 62 percent of his five-year sentence, or 3.1 years." 10 The cost of the sentence is $\$ 54,724$ (3.1 years in prison at $\$ 16,823$ per year plus 1.9 years on parole at $\$ 1,354$ per year.) The Automated Sentencing Information feature also reports that the rate of recidivism for such offenders is 39.6 percent within two years.

- The 120-day "shock" probation sentencing option is available for this offense, but is not among the three options listed as a "recommended sentence." This sentence allows the judge to sentence the offender to prison, but to order a report within 120 days; near the end of the 120day period, the judge can release the offender to probation. Although this option is not among the three "recommended" options, the Automated Sentencing Information feature reports that the recidivism 
for this category of offender sentenced to a "shock" sentence is 39.2 percent.

The data on the cost of sentence are not included in the Sentencing Assessment Report; they are available only on the Automated Sentencing Information feature of the commission's Web site. Judges are free to disregard such data - as they are free to disregard any of the data or recommendations of the commission or the sentencing recommendations as presented by a probation officer in the Sentencing Assessment Report.

\section{Why Cost and Recidivism?}

Why should the cost and recidivism data be included? As a point of argument, a defense attorney might contend that not only is the prison sentence far more costly than the community supervision options, but also has a higher risk of recidivism. A prosecutor may counter that the most effective way to prevent recidivism is to sentence the offender to prison - for at least those years, the offender will be incapacitated from committing crimes, at least on the outside.

\section{Controversy About "Cost"}

The controversy about providing cost data seems legitimate. After all, why should a judge take cost into account? But what about the risk of recidivism? The judge's decision in every case takes into account the safety of the public. But simplistic approaches fail; for instance, a judge could sentence every offender to the statutory maximum. Although the immediate result may be fewer crimes 
committed, the ultimate result probably would be an increase in crimes - that is the result the recidivism data suggest.

These data confirm the "Ma Joad" effect, which I take from a recent rereading of John Steinbeck's THE GRAPES OF WRATH (1939), where Ma Joad, when her son Tommy Joad returns home after four years in prison, asks this worried question: ""I knowed Pretty Boy Floyd [Mr. Floyd was an alumnus of the Missouri State Penitentiary in Jefferson City]. I knowed his ma. They was good folks. He was full a hell, sure like a good boy oughta be. ... I don' know all like this -- but I know it. He done a bad thing an' they hurt 'im, caught 'im an hurt him so he was mad, an' the nex' bad thing he done was mad, an' they hurt him again. An' purty soon he was mean-mad. They shot at him like a varmint, an' he shot back, an' then they run him like a coyote, an' him a-snappin' an' a-snarlin', mean as a lobo. An' he was mad. He wasn't no boy or no man no more, he was jus' a walkin' chunk a mean-mad. But the folks that knowed him didn' hurt 'im. $\mathrm{He}$ wasn' mad at them. Finally they run him down an' killed 'im. No matter how they say it in the paper how he was bad -- that's how it was. ... I got to know, Tommy. Did they hurt you so much? Did they make you mad like that?"

Whether it is Ma Joad or the average sentencing judge, it does seem obvious that locking up an offender in a prison filled with criminals may not improve him, may in fact make him worse, though prison conditions and methods of treatment certainly have improved since the 1930s. 
If the recidivism rates are higher for prison than for non-prison sentences, then why - a judge (or a concerned citizen) might ask - would we spend money for incarceration unless the circumstances of the crime cry out for the retributive effect of a prison sentence or the law requires it. ${ }^{11}$

The idea for including cost, along with recidivism data, on the commission's Web site came from a circuit court judge who routinely has been involved in sentencing. Judges are citizens as well as judges, the judge said (and I paraphrase), and they think about the problem of overspending the state's limited resources on over-incarceration.

To that thought I would add: if some judges do consider cost, in the absence of published data, where do they get the information? My guess is that they guess. If a judge is going to consider the cost to the state's resources of particular sentences, he or she ought to consider information that is accurate. For instance, many people have in their heads the old saw that it is cheaper to send a young man to Harvard than to prison. Not true, actually; Missouri's prison costs $\$ 16,823$ per year, have fallen way behind Ivy League tuitions that are now north of $\$ 50,000$.

The cost data are a way of asking judges - and the public - what are we getting for our correctional dollars? Perhaps costs of incarceration ought not to be considered in assessing punishments that are just - but there is no good reason to keep the question of cost out of the discussion of what justice requires. Judges are 
not required to consider cost, nor are they required to consider the effects of their sentencing on recidivism.

But most judges want to protect the public, they want their sentencing to be rational, and they want the public to get the best bang for the buck. If they want information about cost, why not give it to them?

As importantly, sentencing is an essential government function that judges perform on behalf of the public. The public, in whose behalf sentencing is done, may want to know how its dollars are being spent and whether the spending is cost-effective. One may disagree about the value of the cost-benefit analysis these data may encourage, but there unquestionably is a need for public discussion of this subject. When the Sentencing Advisory Commission put its cost data into the information mix, we knew it would provoke public discussion. And so it did. Good for us.

\footnotetext{
${ }^{1}$ Michael A. Wolff, who served as a judge of the Supreme Court of Missouri, 1998 -2011 and chief justice 2005-2007, was chair of the Missouri Sentencing Advisory Commission from 2004-2011. He is professor of law at Saint Louis University School of Law and codirector of the Center for the Interdisciplinary Study of Law.
} 
${ }^{2}$ See, for example, Monica Davey, "Touching Off Debate, Missouri Tells Judges Cost of Sentences," NEw YoRK Times, Sept. 19, 2010, p. A1; Heather Ratcliffe, “Missouri's Judges Can Weigh Costs of Sentences; First-of-Kind Program Also Gives Access to Data on Possible Recidivism," SAInt Louis Post- DisPatch, Sept 10, 2010, p. A1.

3 The Missouri Sentencing Advisory Commission's BIENNIAL REPORT and UsER GUIDE are available on the commission's Web site, www.mosac.mo.gov. David Oldfield, director of research for the Department of Corrections, produces these reports.

${ }^{4}$ ReCOMmended SENTENCING USER GuIDE 2010-2011, p. 14.

${ }^{5}$ See, generally, Michael A. Wolff, Evidence-Based Judicial Discretion: Promoting Public Safety Through State Sentencing Reform (Annual William J. Brennan Lecture), 83 N.Y.U. Law Review 1389 (2008); Missouri's Information-Based Discretionary Sentencing System, 4 Ohio State Journal of Criminal Law 95 (Fall 2006).

${ }^{6}$ See, for example, MisSOURI SENTENCING AdVISORY COMMISSION SMART SENTENCING, Sentencing Advisory Commission Makes Changes in System of Recommended Sentences, Sentencing Assessment Reports, Vol. 2, Issue 6, Nov. 3, 2010, available at www.mosac.mo.gov.

7 RECOMMENDED SENTENCING USER GUIDE 2010-2011, p. 143-146.

${ }^{8}$ Missouri SENTENCING AdVisory COMmission SMART SENTENCING, Sentencing Information on www.mosac.mo.gov Now Includes Costs of Recommended Sentences and Risk of Reincarceration, Vol. 2, Issue 5 (August 17, 2010).

${ }^{9} I d$.

$10 I d, \mathrm{p} 3$. The Parole Board's guidelines for release on parole for this offender are 45 percent of the term to be spent in prison, but 62 percent of the prison term is what such offenders actually served in prison in on this sentence in Fiscal 2009.

${ }^{11}$ In cases where the offender is a public official who has violated the public trust, for example, judges often sentence more harshly than the range of punishment listed in the commission's System of Recommended Sentencing because the sentencing recommendation does not take into account whether the theft was from a private company or a public agency. 